\title{
Evaluation of Trace Metals in Groundwater of Ekondo-Titi and Environs, Onshore Rio Del Rey, Cameroun
}

\author{
Richard Ayuk II Akoachere ${ }^{*}{ }^{(0)}$, Thomson Areakpoh Eyong1, \\ Marcelle-Carole Pami Ngassam², Raymond Ndip Nkongho ${ }^{3}$, Simon Oko Okpara ${ }^{4}$, \\ Tom Tabi Oben ${ }^{3}$ \\ ${ }^{1}$ Department of Geology, University of Buea, Buea, Cameroon \\ ${ }^{2}$ Department of Agricultural and Environmental Engineering, Pan African University/University of Ibadan, Ibadan, Nigeria \\ ${ }^{3}$ Nigeria Hydrological Services Agency (NIHSA), Abuja, Nigeria \\ ${ }^{4}$ Department of Agronomy and Applied Molecular Sciences, University of Buea, Buea, Cameroon \\ Email: *r.akoachere@ubuea.cm
}

How to cite this paper: Akoachere II, R.A., Eyong, T.A., Ngassam, M.-C.P., Nkongho, R.N., Okpara, S.O. and Oben, T.T. (2019) Evaluation of Trace Metals in Groundwater of Ekondo-Titi and Environs, Onshore Rio Del Rey, Cameroun. Open Access Library Journal, 6: e5791. https://doi.org/10.4236/oalib.1105791

Received: September 16, 2019

Accepted: October 13, 2019

Published: October 16, 2019

Copyright $\odot 2019$ by author(s) and Open Access Library Inc.

This work is licensed under the Creative Commons Attribution International License (CC BY 4.0).

http://creativecommons.org/licenses/by/4.0/

\begin{abstract}
Ekondo-Titi and environs are found between $4.500-4.950 \mathrm{~N}$ and 8.900 9.250E onshore Rio Del Rey Basin in Ndian and Meme Divisions of the South West Region in Cameroon. Evaluation of trace metals in groundwater is among the most important environmental issues related to contamination from anthropogenic and natural sources due to increased urbanization and intensive plantation agriculture in Ekondo-Titi and environs. The study investigated the trace metal content of groundwater sources; determined estimates of the health hazard and pollution risk indices; assessed the health hazard and level of risk to trace metal pollution in Ekondo-Titi and environs. Field measurement of physicochemical parameters and analysis of thirty-seven groundwater samples were analyzed to determine their trace metal content using Inductively Coupled Plasma Mass Spectroscopy ICP-MS. R-mode statistical analysis; Hierarchical Cluster Analysis (HCA) and Pearson's correlation analysis (PCA) of the trace metals with the physico-chemical parameters have been carried out. A risk is the chance, high or low, that the exposure to a hazard will actually cause harm. Four pollution hazards were estimated the average daily dose ADD, carcinogenic risks $\mathrm{CR}$, non-carcinogenic risk hazard quotient $\mathrm{HQ}$ and hazard index HI. Six pollution risks were determined: the Degree of contamination DC, Enrichment factor EF, Ecological risk factor Er, Ecological risk index RI, Pollution load index PLI, and geo-accumulation index Igeo. The results show that the average abundance of trace metals concentrations in the groundwater is in the order: $\mathrm{Fe}>\mathrm{Ba}>\mathrm{Mn}>\mathrm{Zn}>\mathrm{Sr}>\mathrm{Ni}>\mathrm{Cu}>\mathrm{Co}>$ $\mathrm{Pb}>\mathrm{Li}>\mathrm{Cr}>\mathrm{V}>\mathrm{As}>\mathrm{Cd}$. HCA distinguishes the trace metals into two
\end{abstract}


clusters: Cluster one; (01) element Fe; soluble; Cluster two (13) non soluble elements divided into two classes; class one (09) V, As, Cd, Cr, Li, Pb, Co, Ni, $\mathrm{C}$; less enriched; Class two (04) $\mathrm{Mn}, \mathrm{Ba}, \mathrm{Sr}$ and $\mathrm{Zn}$; enriched. PCA shows a very strong positive correlation between $\mathrm{Cr} / \mathrm{V}, \mathrm{Ba} / \mathrm{Li}, \mathrm{Ba} / \mathrm{Mn}, \mathrm{Pb} / \mathrm{Ni}, \mathrm{Pb} / \mathrm{Zn}$, $\mathrm{Cu} / \mathrm{Zn}$ and a moderately strong correlation between $\mathrm{Co} / \mathrm{Mn}, \mathrm{Ba} / \mathrm{Co}, \mathrm{Ba} / \mathrm{EC}$ and $\mathrm{Ba} / \mathrm{TDS}$. The values of groundwater pollution hazard indices range as follows; ADD (5E-06 - 0.078), CR (4.3E-06 - 0.002), HQ (3E-04 - 1.23) and HI $(0.03-1.23)$. And those of the pollution risk indices are DC ( -13.59 to -5.62$)$, EF (0.79 - 843.94), Er (-29.84 - 0.19), RI (-62.07 to -45.53$)$, PLI (-0.044 $0.046)$ and Igeo $(0$ - 995.4). The groundwater pollution hazard indices ADD and CR are less than 1 in the categories of insignificant pollution health hazard, are below the acceptable guideline values whereas HQ and HI are above 1, likely to pose health hazards. The pollution health risk indices DC, EF, Er, RI, PLI, and Igeo are all below the acceptable guideline values. The enrichment factor EF showed that the sources of these metals are geogenic and anthropogenic processes. Barium is the most enriched element in the study area; this could be attributed to agricultural fertilizers. Igeo values indicate groundwater is no pollution to moderately pollution risk from $\mathrm{Li}, \mathrm{V}, \mathrm{Cr}, \mathrm{Co}$, $\mathrm{As}, \mathrm{Cd}, \mathrm{Pb}$ while groundwater has a strong pollution risk from $\mathrm{Ba}$ and extreme pollution risk from $\mathrm{Mn}, \mathrm{Sr}, \mathrm{Fe}$ and $\mathrm{Zn}$, though the concentrations of the trace metals are below WHO guidelines. Thus, from the health hazard indices and pollution risk indices on trace metals, the groundwater in Ekondo-Titi and environs is safe for drinking. The severity of metal toxicity is governed by several factors, such as dose, nutrition, age, and even life style. Therefore, these low trends that indicate the absence of human health hazards and health risks, the groundwater, might not guarantee the complete and permanent absence of human health hazards and risks due to an increasing level of environmental pollution that might be imposed by the increasing plantation agriculture in this area. Groundwater sources might become a potential sink of contaminants; this is the reason for recommending a constant monitoring and implementation program in Ekondo-Titi and environs.

\section{Subject Areas}

Environmental Sciences, Hydrology

\section{Keywords}

Trace-Metal, PCA, HCA, Health-Hazard-Indices, Pollution Risks-Indices, Rio-Del-Rey, Ekondo-Titi, Cameroon

\section{Introduction}

Ekondo-Titi and environs are found between $4.500-4.950 \mathrm{~N}$ and $8.900-9.250 \mathrm{E}$ as in Figure 1, in Ndian and Meme Divisions of the South West Region in Cameroon; an agro-industrial zone of Cocoa, Banana, Rubber and Palm-oil plantations, all of which are exported and dependent on groundwater for processing. 
The presence of agro-industries has led to unprecedented population growth and urbanization around this area resulting in a high demand for water that has now exceeded supply.

Water is one of the essentials that support all forms of animal and plant life [1] and it is generally obtained from surface water such as freshwater lakes, rivers and streams and groundwater such as springs and well water.

The study of trace metal deposition and accumulation is of increasing interest because of the awareness that trace metals present in groundwater may have negative consequences on human health and on the environment when they exceed the maximum contamination levels. Because of the absence of treatment of groundwater before drinking in Ekondo-Titi and environs, it is of great importance to assess the trace metal content. The assessment of trace metal quality of groundwater used by the inhabitants of this area is sparse. Environmental pollution by trace metals is due to both geogenic; natural processes such as weathering of minerals and anthropogenic activities related to industry, agriculture, burning of fossil fuels, vehicular emission, mining and metallurgical processes and their waste disposal.

Trace metals are naturally part of the environment and can be found in soils and rocks and also dissolved in rivers, streams and groundwater. Despite the natural occurrence of trace metal in the environment, the main sources of their accumulation in nature are human activities [2]. Trace metals are chemical components found in low concentrations, in mass fractions of ppm or less, in water, organisms and soil [3]. Some trace metals are essential as micronutrients $\mathrm{Cu}, \mathrm{Fe}, \mathrm{Mn}, \mathrm{Ni}$ and $\mathrm{Zn}$ for life processes in plants and microorganisms, while others $\mathrm{Cd}, \mathrm{Cr}$ and $\mathrm{Pb}$ have no known physiological activity, but are proven detrimental beyond a certain limit which is very much narrow for some elements like Cd $0.01 \mathrm{mg} / \mathrm{L}, \mathrm{Pb} 0.10 \mathrm{mg} / \mathrm{L}$ and $\mathrm{Cu} 0.050 \mathrm{mg} / \mathrm{L}$ [4].



Figure 1. Location map for measurements and sample collection in Ekondo-Titi and environs. 
A hazard is any agent that can cause harm/damage to humans or the environment. Risk is the possibility of danger or injury; an uncertain event/condition that, if it occurs, has an effect on the subject; the chance, high or low, that exposure to the hazard will actually cause harm. Health risk assessment encompasses four steps: Hazard identification, dose-response assessment, exposure assessment, and risk characterization.

The present study investigated the trace metal content of groundwater sources, determined estimates of the health hazard and pollution risk indices, assessed the health hazard and level of risk to trace metal pollution in Ekondo-Titi and environs.

\subsection{Climate}

This area is characterized by an equatorial climate, but its dominant lowland topography (exempting the highlands towards the northeast), and its proximity towards the sea ensures an equatorial maritime climate type along the Atlantic coast. The Climate is characterized by two seasons (rainy and dry) determine by the apparent movement of the overhead sun and seasonal tropical winds. Generally, annual rainfall is high. It ranges from $2000 \mathrm{~mm}$ on the lowlands and 4000 $\mathrm{mm}$ on the leeward slopes of Mount Cameroon and the Rumpi Hills [5].

\subsection{Relief}

The study area stands out as an area of gentle relief with lowlands in the south, west, and North West. Towards the east and North-East, the relief changes to hilly landscape. Some areas in the East have an altitude of up to $1000 \mathrm{~m}$ above sea level. Close to the Atlantic Ocean are the mangrove swamps, several creeks, and sand-spits that stretch from the muddy coast lines of Meme river delta in Mbonge, Ekondo-Titi to the Ndian River Basin.

\subsection{Hydrology}

The main rivers include rivers; Ndian, and Melange which both take their rise from the Rumpi Hills and River Meme from the flanks of Mt Cameroon and the Bakossi Forest Reserve and they flow into the Atlantic Ocean respectively.

\subsection{Geology}

Cameroon's geology is made of different rock types;

1) Precambrian basement rocks covering about $77 \%$ of Cameroon and underlie,

2) Sedimentary rocks covering $9 \%$ are of Cretaceous to the Cenozoic Era intruded in some areas by,

3) The Tertiary to recent volcanics covering $10 \%$ found generally along the Cameroon Volcanic Line (CVL),

4) Over a, b and c, above along major river channels, deltas and seashores are recent alluvium that make up some $4 \%$. 
Bakassi Peninsula is found in the Rio Del Ray basin (Coastal basin) which is one of the Equatorial Atlantic marginal basins in the Gulf of Guinea, covering $2500 \mathrm{~km}^{2}$ and dipping ocean-wards with about $6000 \mathrm{~m}$ thick of sediments ranging from Cretaceous to Recent. The basin proper is bordered to the west and northwest by the contemporaneous Niger Delta Basin, limited to the south by the Island of Bioko, the north by the Rumpi Hills and to the east by the Cameroon Volcanic Line (CVL) separating the Rio Del Ray basin from the Douala Ba$\sin$.

The Rio Del Ray basin and the Douala basin are genetically related and were linked together constituting one composite basin, which was itself attached to the Niger Delta in Nigeria. There are four Formations of the Rio Del Ray basin; Akata, Agbada, Benin and the Isongo formations averaging a depth of $2.5 \mathrm{~km}$.

The Akata Formation is about $600 \mathrm{~m}-6000 \mathrm{~m}$ thick. The sands are continental slope channel-fills and turbidities.

The Agbada Formation overlies the Akata Formation and consists of interbedded sand and shales with thickness of about $300 \mathrm{~m}-4500 \mathrm{~m}$. The coarse clastic beds are the oil reservoirs of up-to-date discovered oilfields.

The Benin Formation is the topmost Tertiary sequence of the Niger Delta and continues eastwards into the Rio Del Ray basin as a fringe zone of shales diapirs, sandy clays, dark-green sandstones, lignites and fragments of volcanic rocks. The Benin Formation has a thickness of about $1890 \mathrm{~m}-2300 \mathrm{~m}$ at the center.

The Isongo Formation is encountered mostly south-east of the Rio Del Ray basin and represent a mixed phase of marine shales and fan sands.

The Formations in the Rio Del Ray basin that outcrops onshore are Aptian to Albian Mundeck, coarse fluvial sandstone and the late cretaceous Mungo and Logbaba, shallow marine limestones, sandstones and shales which are overlain unconformably by Tertiary non marine sands and silts. Offshore the sequence above the unconformity is Eocene to recent, the Akata Formation, diachronous pro-deltaic shales are overlain by the Agbada, deltaic front sandstones, shales and the Benin, fluvial sands. The Rio Del Ray basin also contain some features of the Cameroon Volcanic Line (CVL), an alignment of volcanic massifs trending north-south from the island of Pagalu to lake Tchad, consisting of a hosts and grabens and is an example of intraplate volcanism as discussed in [6] [7] [8] [9]. The CVL is a "Y" shape long chain of Tertiary to Recent Volcanic complexes with a general NE-SW orientation and spreads from the South Atlantic into the interior of Africa. Amongst the 60 volcanic craters that litter the CVL, Mount Cameroon is the most active. The CVL extends more than $900 \mathrm{~km}$ across Cameroon from Bui and Adamawa plateau in the north of mount Cameroon and Equatorial Guinea [10], it then continues for another $700 \mathrm{~km}$ through the Atlantic island of Principe, Sao Tome and Palagu [11]. The CVL was initiated by an upwelling mantle plume since the onset of the continental breakup in the early cretaceous. It generally consists of basalts to ryholite nephelinites, phenolites and trachytes with volcanic rocks found within the volcanoes [8]. The continental 
volcanoes are Mount Fako, Rumpi hills, Manengouba, Bambuotus, Oku and the volcanic rocks of Kapsiki plateau and the Benue valley [12]. The oceanic part is made up of Annabon, Sao-Tome, Bioko and Principi [13]. The continental sector of the CVL seems to follow old suture zones between two seismically and paleomagnetically distinct lithospheric blocks [14] [15]. The major rock formations in Bakassi Peninsular onshore around Ekondo-Titi and environs are; gneiss, meta-sediments (Cretaceous; Tertiary sediments) and Recent volcanics as in Figure 2.

The Cretaceous-Tertiary sediments vary according to the environment of deposition and are essentially clastic, consisting of sands, sandstone, and conglomerates with subsidiary clays, shales, marls and lignites outcropping beyond the southern catchments' limits with a thickness of about 68 meters. The Tertiary-Quaternary basaltic lavas associated with the Cameroon Volcanic Line, as part of the major Foumban shear zone, intruded the sediments during the Miocene [16]. This magmatic activity resulted in extensive lava flows that formed the Rumpi hills in the north and intruded the sediments in the south. These extrusive events lapsed for sufficient time allowing a substantial layer of ash and basaltic lava flows to become interbedded with the extensive alluvium, deltaic and lacustrine deposits and in the study area columnar basalts are common intrusive. Recent alluvium is being deposited along the present coastline and margins of the delta of the Meme, Malange and Ndian rivers.

\subsection{Hydrogeology}

The aquifer(s) in this area are heterogeneous intercalation of fluvio-deltaic and marines conglomerates, sands, sandy clays, lateritic silts, silty clays, clayey sands, shales, marl lenses and the fractured recent volcanics which constitute good aquifers in most areas around Ekondo-Titi, Mbonge, Bongongo, Illor and Lobe Town.



Figure 2. Geologic map of Ekondo-Titi and environs made up of four rock types; gneiss, metasediments, recent volcanism and granites. 


\section{Materials and Methods}

\subsection{Sample Collection, Pre-Treatment and Chemical Analysis}

Thirty-seven samples were collected from pre-selected wells, boreholes and springs. Site selection was based on spatial distribution of the wells, boreholes, springs and population. At each site, groundwater temperature, electrical conductivity, total dissolve solids and $\mathrm{pH}$ value were measured in situ, using portable field $\mathrm{pH}, \mathrm{EC}$ and TDS meters as shown in Table 1.

Prior to sampling, the pre-cleaned sample bottles were rinsed with the sample water. The well water was withdrawn with the use of a $50 \mathrm{ml}$ syringe, and then filtered through the $0.2 \mu \mathrm{m}$ mixed cellulose ester filter into $50 \mathrm{ml}$ high-density polyethylene HDPE containers. The sample was preserved by acidifying to $\mathrm{pH}<$ 2 by adding nitric acid and sealed using a permanent tape. The samples were labelled and put into the sample bottle collection bag. The filtered groundwater samples were later shipped to the Activation laboratory in Canada for trace metal analysis by Inductive Coupled Plasma Mass Spectrometer ICP-MS.

\subsection{Hazard Identification}

Involves the identification of the chemical of concern and documenting its toxic effects on human beings after field mapping. It also involves the characterization of potential contaminants and their relative mobilities [17] as shown in Table 2.

Table 1. Field Equipment, Softwares, their specifications and functions used in the study.




Table 2. Trace metals and their effects [3].

\begin{tabular}{ll}
\hline Component & Toxicity effects \\
\hline $\mathrm{Zn}$ & Zinc suppresses copper and iron intake causing peripheral neuropathy. \\
$\mathrm{Co}$ & $\begin{array}{l}\text { Active in vitamin } \mathrm{B} 12 \text { and in chemical reactions. Excess causes hearth } \\
\text { failures. }\end{array}$ \\
$\mathrm{Cu}$ & Excess leads to acute gastrointestinal problems \\
$\mathrm{Cr}$ & Excess may result in renal failures. Excess of $\mathrm{Cr}^{+6}$ is carcinogenic. \\
$\mathrm{Mn}$ & $\begin{array}{l}\text { Manganese toxicity result in neurological disorder; manganism, with symptoms } \\
\text { of tremors }\end{array}$ \\
$\mathrm{Cd}$ & Cadmium compounds are known human carcinogens. \\
$\mathrm{V}$ & Vanadium causes albumin in urine \\
$\mathrm{Ni}$ & Nickel is carcinogenic and causes neurological deficits \\
$\mathrm{As}$ & Arsenic causes cancer of the skin, lungs, liver and bladder. \\
$\mathrm{Sb}$ & Antimony causes gastrointestinal problems, kidney damage or liver damage \\
$\mathrm{Al}$ & Aluminium causes neurotoxicity. \\
$\mathrm{Pb}$ & Lead is a carcinogen affecting every organ and system in the body. \\
\hline
\end{tabular}

\subsection{Exposure Assessment}

This is the process of measuring or estimating the intensity, frequency and duration of human exposures to an environmental agent [17]. The main exposure pathway taken into consideration in this study was intake of the metals through water consumption. The daily environmental exposures to metals were assessed for carcinogenic and non-carcinogenic elements.

The intakes of metals through ingestion of groundwater were calculated using Equation (1) [18].

$$
A D D=\frac{C \cdot I R \cdot E D \cdot E F}{B W \cdot A T \cdot 360}
$$

where;

$A D D s$ are Exposure duration ( $m g / k g$-day) -The Average Daily Dose $(A D D)$ of the contaminant through water pathway indicates the quantity of chemical substance ingested per kilogram of body weight per day.

$C$ is Concentration of contaminant in the environmental media (e.g., $\mu g / L$, $m g / L)$.

IR is Ingestion rate per unit time (e.g., $\mathrm{mg} /$ day or L/ day).

$E F$ is Exposure frequency (dayl year).

$E D$ is Exposure duration (years).

$B W$ is Body weight of receptor $(\mathrm{kg})$.

$A T$ is Averaging time = life expectancy (years) 365 is the conversion factor from years to days.

For non-carcinogenic effects, $A T=E D$ in days, carcinogenic effect, $A T=70$ years or 25,550 days. 


\subsection{Dose-Response/Toxicity Assessment}

This is the quantitative relationship that indicates the contaminants degree of toxicity to exposed species. It also involves the identification of the toxicity criteria used to evaluate human health risk associated with the chemical of concern in the study area. The amount of chemical that can affect human health is estimated. The Reference Dose RfD is used for non-carcinogen risk.

\subsection{Risk Characterization}

This is the final phase of the risk assessment process. In this phase, cumulative exposure and dose-response assessments are integrated to yield probabilities of effects occurring in human beings under specific exposure conditions and time scales. Also incorporated is information from hazard identification, exposure assessment, toxicity assessment and risk estimation to evaluate the potential risk to residents.

\subsection{Carcinogenic Risk Assessment}

Carcinogenic risks were determined by calculating the potential of an individual to develop cancer as a result of cumulative exposure to each potential carcinogen over a lifetime. For carcinogen, identified by a weight-of-evidence classification of the chemical [19]. The estimated daily dose and the cancer slope factor are multiplied together to find the lifetime cancer risk posed by the chemical. Cancer slope factors are estimates of carcinogenic potency and were used to relate estimated daily dose of the trace metal over a lifetime exposure to the lifetime probability of excess tumors Equation (2) [19] [20] [21].

$$
C R=A D D \cdot S F
$$

$C R$ is the excess probability of developing cancer over a lifetime as a result of exposure to a contaminantor carcinogenic risk. It is unit less, SF is the slope factor of the contaminant $[\mathrm{mg} / \mathrm{kg} / \mathrm{d}]^{-1}$.

\subsection{Non Carcinogenic Risk Assesment}

Non-carcinogenic hazards are characterized by the hazard quotient $(H Q) . H Q$ is a unitless number that is expressed as the probability of an individual suffering an adverse effect. To estimate noncarcinogenic risk, the hazard quotient $(H Q)$ was calculated using Equation (3) [22].

$$
H Q=\frac{A D D}{R f D}
$$

$R f D$ is the reference dose $\mathrm{mg} / \mathrm{kg} / \mathrm{d}$. It represents a toxicity index of a daily exposure to the population in comparison to a safe level of exposure orally over a lifetime [23].

\subsection{Harzard Index (HI)}

It is the toxic risks due to all the potentially hazardous substances present in the 
same media simultaneously [24]. Since more than one toxicant is evaluated, the interactions of all the toxicants were considered and assumed to be cumulative. Thus, the $H I$ was calculated by summing all the $H Q$ for all toxicants, Equation (4) $[22]$.

$$
H I=\sum_{i=1}^{n} H Q_{i}
$$

\subsection{Pollution Risk Evaluation Indices}

Generally, pollution indices are estimated for a specific use of the water under consideration. The trace metal degree of contamination (DC), enrichment factor $(\mathrm{EF})$, ecological risk index (Er), potential ecological risk index (RI), pollution load index (PLI) and geo-accumulation index (Igeo) were used to evaluate the pollution potential of Ekondo-Titi and environs as in Table 3.

\section{Results and Discussion}

\section{Physicochemical Parameters}

The physicochemical parameters of groundwater in Ekondo-Titi and environs: temperature, $\mathrm{pH}, \mathrm{EC}$ and TDS were measured in-situ for 184 wells and springs and summarized in Table 4.

\subsection{Water Level Fluctuations}

Depth-to static water level (m) of groundwater ranged from: 0.7 - 3 as in Figure 3. Areas with shallow depths to static water levels such as Besingi, Masore and Ekondo Titi are susceptible to pollution if the wells are not appropriately constructed and protected whereas areas with deep water levels could be more protected from pollution since run-off does not enter into the well during rainy season if well constructed.

\subsection{Groundwater Flow Direction}

Groundwater flows towards the Southern and Northwestern part of the study area which could probably be a recharge zone. This recharge zone is at Mbonge and Besingi as in Figure 4.

Table 3. Formulae for calculation of pollution indices.

\begin{tabular}{cccc}
\hline SN & Trace element pollution indices & Formulae & Reference \\
\hline 1 & Degree of Contamination & $D C=\sum_{i=1}^{n} C_{f}^{i}$ & {$[25]$} \\
2 & Enrichment factor & $E R=\frac{(\text { Ci } / \text { Cie }) \text { sample }}{(\text { Ci } / \text { Cie }) \text { background }}$ & {$[26]$} \\
3 & Ecological risk factor & $E_{r}^{i}=T_{r}^{i} \times C_{f}^{i}$ & {$[27]$} \\
4 & Ecological risk index & $R I_{i}=\sum_{i=1}^{n} E_{r}^{i}$ & {$[27]$} \\
5 & pollution load index & $P L I=\sqrt[n]{C_{f 1} \times C_{f 2} \cdots C_{f n}}$ & {$[28]$} \\
6 & Geo-accumulation index & $I_{g e o}=\log _{2}\left[C_{i} /\left(1.5 C_{r i}\right)\right]$ & {$[29]$} \\
\hline
\end{tabular}


Table 4. Field determined physicochemical parameters; electrical conductivity (EC), pH, total dissolved solids (TDS) and temperature of groundwater in study area.

\begin{tabular}{cccc}
\hline Parameter & Min & Max & Mean \\
\hline $\mathrm{T}\left({ }^{\circ} \mathrm{C}\right)$ & 26.1 & 30.2 & 28 \\
$\mathrm{PH}$ & 4.2 & 7.6 & 5.703 \\
$\mathrm{EC}(\mathrm{mS} / \mathrm{cm})$ & 2 & 32 & 11.26 \\
$\mathrm{TDS}(\mathrm{mg} / \mathrm{L})$ & 1.34 & 21.44 & 7.544 \\
\hline
\end{tabular}



Figure 3. Depth to static water level; high values are at Mundemba and Funge whereas low values are at Besingi, Masore and Ekondo Titi.



Figure 4. Groundwater flow direction in study area indicating that water flows towards the Southeastern part of Ekondo-Titi and environs.

\subsection{Temperature}

Temperature values of groundwater ranged from: $26.1^{\circ} \mathrm{C}-28.9^{\circ} \mathrm{C}$ as in Figure 5 . The temperature variation is similar in the different areas, suggesting a single aquifer since groundwater in the same aquifer have similar temperature. This is also indicative of a phreatic aquifer as the temperatures are close to air temperatures. 


\section{4. $\mathrm{pH}$}

The $\mathrm{pH}$ value of most of the groundwater samples in the study area ranged from $4.2-7.6$ as in Figure 6. The values of $\mathrm{pH}$ of a water sample are recognized as an index of classifying groundwater as acidic $<5.5$, slightly acidic $5.5-6.5$, neutral 6.5 - 7.5, slightly alkaline $7.5-8$, moderately alkaline $8-9$ and alkaline $>9$. This clearly shows that the groundwater in the study area is acidic to slightly alkaline.

\subsection{Electrical Conductivity}

The EC ranged from $2-30 \mathrm{mS} / \mathrm{m}$ as in Figure 7. The low electrical conductivity is due to less solute concentration in the groundwater probably due to short contact time with the rocks or occurrence of non-soluble host rocks at the P-T conditions.

\subsection{Total Dissolved Solids}

The total dissolved solids ranged from $0.80-6.2 \mathrm{mg} / \mathrm{L}$ as in Figure 8. These TDS values are $<500 \mathrm{mg} / \mathrm{L}$ thus indicating that the groundwater in Ekondo-Titi and environs is fresh.



Figure 5. Spatial variation of groundwater temperatures; Temperatures are generally higher at, Ilor, Masore, Big Nganjo, Mabonji, Mbonge, Small Nganjo and Ekondo Titi while low values are at Besingi and Funge.



Figure 6. Spatial variation of $\mathrm{pH}$; High $\mathrm{pH}$ values are at Ekondo Titi, Illor, Lobe village, Masore and Funge while low values are at Besingi and Big Small Nganjo, Mabongi and Bole I. 




Figure 7. Spatial variation of Electrical Conductivities $(\mathrm{mS} / \mathrm{m})$; EC is at maximum at Mbonge, Big Nganjo and Small Nganjo Illor and Ekondo whereas Titi low values are at Funge, Masore and Besingi.



Figure 8. Spatial variation of total dissolved solids $\mathrm{mg} / \mathrm{L}$; TDS is at maximum at Mbonge, Big Nganjo and Small Nganjo Illor and Ekondo whereas Titi low values are at Funge, Masore and Besingi.

The results for twelve samples of trace metal analysis ICP-MS are presented in Table 5. The concentrations of fourteen trace metals; $\mathrm{Zn}, \mathrm{Pb}, \mathrm{Co}, \mathrm{Cu}, \mathrm{Cr}, \mathrm{Mn}, \mathrm{Sr}$, $\mathrm{Cd}, \mathrm{V}, \mathrm{Fe}, \mathrm{Ni}, \mathrm{As}, \mathrm{Li}, \mathrm{Ba}, \mathrm{Mn}$, and $\mathrm{Pb}$ were evaluated. The concentrations of these trace metals are below the [30] allowable limit. However, the cumulative effects of long term consumption of these trace metals in the groundwater necessitated a health hazard and pollution evaluation risk assessment since [31] reported the occurrence of Arsenic in groundwater in this area.

\subsection{Pearson's Correlation Analysis (PCA) between Trace Metals and Physico-Chemical Parameters}

Correlation between trace metals in groundwater within the study area was carried out using Pearson's correlation analysis (PCA) as shown in Table 6 to establish the relationships that exist between the variables; trace metals and the physico-chemical parameters. $r$ values $>0.5$ or $<-0.5$ are significant, 0.72 strong (moderate) and 0.80 Very strong correlation. 
Table 5. Trace metal concentration $(\mu \mathrm{g} / \mathrm{L})$ and basic statistics of groundwater in Ekondo-Titi and environs.

\begin{tabular}{|c|c|c|c|c|c|c|c|c|c|c|c|c|c|c|c|}
\hline $\mathrm{SN}$ & Location & $\mathrm{Li}$ & $\mathrm{V}$ & $\mathrm{Cr}$ & Mn & $\mathrm{Fe}$ & Co & $\mathrm{Ni}$ & $\mathrm{Cu}$ & $\mathrm{Zn}$ & As & $\mathrm{Sr}$ & $\mathrm{Cd}$ & $\mathrm{Ba}$ & $\mathrm{Pb}$ \\
\hline 1 & Mundemba & 0.69 & 0.19 & 0.63 & 16.15 & 59.53 & 0.94 & 3.30 & 4.20 & 24.73 & 0.06 & 11.09 & 0.13 & 10.81 & 1.74 \\
\hline 2 & Besingi & 0.96 & 0.19 & 0.40 & 110.79 & 792.62 & 3.91 & 3.86 & 15.95 & 20.32 & 0.90 & 19.35 & 0.10 & 25.47 & 1.13 \\
\hline 3 & Illor & 0.11 & 0.28 & 0.21 & 5.32 & 74.09 & 1.62 & 0.97 & 4.99 & 5.18 & 0.40 & 31.25 & 0.03 & 4.39 & 0.83 \\
\hline 4 & Funge & 0.23 & 0.27 & 0.85 & 15.83 & 197.47 & 1.48 & 2.97 & 5.21 & 8.27 & 0.31 & 30.91 & 0.05 & 17.89 & 1.03 \\
\hline 5 & Masore B 1 & 0.19 & 0.06 & 0.20 & 13.11 & 28.76 & 0.64 & 1.65 & 2.22 & 6.54 & 0.21 & 12.42 & 0.06 & 10.27 & 0.85 \\
\hline 6 & Masore B 2 & 0.21 & 0.09 & 0.29 & 17.15 & 54.56 & 1.17 & 3.08 & 6.23 & 37.65 & 0.15 & 11.22 & 0.19 & 25.00 & 1.28 \\
\hline 7 & Ekondo Titil & 0.52 & 0.09 & 0.20 & 44.30 & 33.74 & 2.58 & 3.53 & 3.07 & 14.46 & 0.36 & 55.90 & 0.06 & 47.44 & 0.56 \\
\hline 8 & Ekondo Titi2 & 0.47 & 0.20 & 0.41 & 82.07 & 2488.43 & 4.08 & 6.10 & 4.71 & 14.75 & 0.26 & 56.83 & 0.07 & 54.18 & 0.76 \\
\hline 9 & Ekondo Titi3 & 0.44 & 0.10 & 0.15 & 65.04 & 122.44 & 2.08 & 67.41 & 18.07 & 5.99 & 0.24 & 57.87 & 0.04 & 93.02 & 0.55 \\
\hline 10 & Ekondo Titi4 & 0.31 & 0.27 & 0.18 & 21.40 & 76.92 & 1.18 & 1.64 & 1.38 & 2.95 & 0.25 & 60.55 & 0.02 & 72.08 & 0.64 \\
\hline 11 & Ekondo Titi5 & 0.77 & 0.08 & 0.15 & 21.43 & 38.84 & 0.51 & 1.80 & 2.82 & 9.10 & 0.04 & 11.36 & 0.05 & 25.12 & 0.76 \\
\hline 12 & Ekondo Titi6 & 0.73 & 0.20 & 0.32 & 23.05 & 128.33 & 0.82 & 2.07 & 5.31 & 57.32 & 0.08 & 13.87 & 1.61 & 44.29 & 1.31 \\
\hline 13 & Ekondo Titi7 & 2.27 & 0.35 & 0.76 & 125.79 & 211.01 & 4.00 & 11.22 & 12.12 & 84.55 & 0.23 & 63.22 & 0.25 & 159.60 & 3.47 \\
\hline 14 & Ekondo Titi8 & 1.22 & 0.58 & 0.91 & 24.61 & 319.55 & 1.49 & 12.55 & 22.95 & 632.25 & 0.12 & 23.34 & 0.39 & 46.92 & 6.03 \\
\hline 15 & Ekondo Titi9 & 0.60 & 0.13 & 0.20 & 13.81 & 69.10 & 0.84 & 2.16 & 2.51 & 37.94 & 0.05 & 9.55 & 0.11 & 42.84 & 0.98 \\
\hline 16 & Ekondo Titi10 & 2.18 & 0.04 & 0.16 & 125.33 & 19.91 & 2.90 & 5.28 & 2.32 & 15.95 & 0.25 & 32.11 & 0.05 & 93.26 & 0.75 \\
\hline 17 & Ekondo Titil1 & 2.17 & 0.57 & 1.05 & 89.46 & 236.31 & 2.96 & 7.46 & 12.18 & 96.82 & 0.15 & 27.14 & 0.27 & 84.76 & 4.15 \\
\hline 18 & Ekondo Titi12 & 0.45 & 0.22 & 0.24 & 38.71 & 57.55 & 1.42 & 2.31 & 3.22 & 24.37 & 0.11 & 22.21 & 0.06 & 42.29 & 0.92 \\
\hline 19 & Ekondo Titi13 & 0.40 & 0.15 & 0.21 & 96.57 & 56.85 & 1.84 & 3.13 & 1.84 & 7.00 & 0.18 & 80.48 & 0.07 & 65.87 & 0.80 \\
\hline 20 & Ekondo Titi14 & 0.79 & 0.12 & 0.32 & 50.12 & 107.89 & 2.92 & 6.74 & 5.19 & 37.84 & 0.08 & 23.49 & 0.11 & 52.79 & 1.51 \\
\hline 21 & Ekondo Titi15 & 1.09 & 0.24 & 1.03 & 85.41 & 157.39 & 6.61 & 15.85 & 14.02 & 112.87 & 0.22 & 48.73 & 0.20 & 179.80 & 3.55 \\
\hline 22 & Ekondo Titi16 & 0.39 & 0.33 & 1.26 & 10.14 & 78.46 & 0.65 & 2.77 & 4.99 & 5.01 & 0.03 & 25.90 & 0.03 & 20.61 & 0.92 \\
\hline 23 & Ekondo Titi17 & 0.40 & 0.49 & 0.74 & 8.89 & 65.82 & 0.56 & 2.80 & 4.75 & 21.11 & 0.05 & 33.27 & 0.10 & 17.50 & 1.14 \\
\hline 24 & Ekondo Titi18 & 0.29 & 0.13 & 0.23 & 29.47 & 27.79 & 0.93 & 2.67 & 3.36 & 8.44 & 0.03 & 28.39 & 0.06 & 19.79 & 0.87 \\
\hline 25 & Ekondo Tit19 & 0.85 & 0.08 & 0.14 & 68.34 & 42.38 & 5.12 & 7.81 & 2.58 & 9.03 & 0.15 & 49.46 & 0.06 & 114.65 & 1.01 \\
\hline 26 & Lobe Village1 & 1.46 & 0.08 & 0.14 & 118.79 & 55.74 & 0.96 & 1.93 & 1.22 & 4.21 & 0.03 & 58.86 & 0.02 & 22.72 & 0.65 \\
\hline 27 & Lobe Village2 & 1.20 & 0.27 & 0.49 & 177.43 & 336.68 & 2.07 & 6.11 & 8.62 & 81.63 & 0.14 & 122.04 & 0.17 & 35.76 & 3.47 \\
\hline 28 & Lobe Village3 & 0.26 & 0.23 & 0.19 & 9.51 & 1823.32 & 0.21 & 1.07 & 1.59 & 62.45 & 0.14 & 2.37 & 0.03 & 11.03 & 0.56 \\
\hline 29 & Bongongo & 3.39 & 0.08 & 0.31 & 538.22 & 69.97 & 17.83 & 28.77 & 6.29 & 34.31 & 0.22 & 75.16 & 0.14 & 340.35 & 1.07 \\
\hline 30 & Mbonge 1 & 3.64 & 0.42 & 0.41 & 62.49 & 133.17 & 1.84 & 4.01 & 1.90 & 5.22 & 0.40 & 62.18 & 0.04 & 126.05 & 0.55 \\
\hline 31 & Mbonge 2 & 2.64 & 0.13 & 0.21 & 142.99 & 212.79 & 5.40 & 7.56 & 3.61 & 26.28 & 0.51 & 56.72 & 0.11 & 261.69 & 0.79 \\
\hline 32 & Mbonge3 & 5.76 & 0.31 & 0.75 & 142.53 & 456.34 & 8.07 & 12.41 & 5.92 & 45.26 & 0.39 & 62.08 & 0.13 & 278.74 & 2.18 \\
\hline 33 & Mbonge 4 & 5.38 & 0.08 & 0.30 & 94.03 & 186.96 & 1.95 & 3.60 & 1.62 & 9.97 & 0.13 & 49.37 & 0.03 & 122.45 & 0.76 \\
\hline 34 & Small Nganjo & 0.80 & 0.28 & 0.48 & 25.25 & 416.02 & 1.17 & 3.72 & 5.28 & 77.83 & 0.07 & 8.50 & 0.12 & 22.12 & 2.76 \\
\hline 35 & Big Nganjo & 4.66 & 0.34 & 0.73 & 35.56 & 466.04 & 3.00 & 4.63 & 3.60 & 29.29 & 0.68 & 200.56 & 0.08 & 162.47 & 1.04 \\
\hline 36 & Mabonji & 1.39 & 0.12 & 0.37 & 52.87 & 173.96 & 2.50 & 15.00 & 2.42 & 31.17 & 0.07 & 12.60 & 0.06 & 51.81 & 1.37 \\
\hline 37 & Bole I & 1.65 & 0.12 & 0.87 & 34.13 & 157.72 & 3.94 & 13.33 & 2.32 & 18.42 & 0.05 & 21.46 & 0.03 & 107.19 & 0.70 \\
\hline Min & & 0.11 & 0.04 & 0.14 & 5.32 & 19.91 & 0.21 & 0.97 & 1.22 & 2.95 & 0.03 & 2.37 & 0.02 & 4.39 & 0.55 \\
\hline $\operatorname{Max}$ & & 5.76 & 0.58 & 1.26 & 538.22 & 2488.43 & 17.83 & 67.41 & 22.95 & 632.25 & 0.90 & 200.56 & 1.61 & 340.35 & 6.03 \\
\hline Mean & & 1.38 & 0.21 & 0.45 & 71.25 & 271.20 & 2.76 & 7.66 & 5.69 & 46.66 & 0.21 & 42.48 & 0.14 & 78.73 & 1.44 \\
\hline
\end{tabular}

The trace metal with the highest concentration is FE with a maximum value of $2488.43 \mathrm{ug} / \mathrm{L}$ measured at Ekondo Titi 2. 
Table 6. Correlation matrix of $\mathrm{r}$ values for trace metals and physico-chemical parameters in Ekondo-Titi and environs.

\begin{tabular}{|c|c|c|c|c|c|c|c|c|c|c|c|c|c|c|c|c|c|c|}
\hline & $\mathrm{Li}$ & $\mathrm{V}$ & $\mathrm{Cr}$ & Mn & $\mathrm{Fe}$ & Co & $\mathrm{Ni}$ & $\mathrm{Cu}$ & $\mathrm{Zn}$ & As & $\mathrm{Sr}$ & $\mathrm{Cd}$ & $\mathrm{Ba}$ & $\mathrm{Pb}$ & Temp & $\mathrm{pH}$ & EC & TDS \\
\hline $\mathrm{Li}$ & 1 & & & & & & & & & & & & & & & & & \\
\hline $\mathrm{V}$ & 0.12 & 1 & & & & & & & & & & & & & & & & \\
\hline $\mathrm{Cr}$ & 0.18 & 0.68 & 1 & & & & & & & & & & & & & & & \\
\hline Mn & 0.44 & -0.18 & -0.08 & 1 & & & & & & & & & & & & & & \\
\hline $\mathrm{Fe}$ & -0.03 & 0.11 & 0.01 & -0.02 & 1 & & & & & & & & & & & & & \\
\hline Co & 0.47 & -0.13 & 0.08 & 0.89 & 0.03 & 1 & & & & & & & & & & & & \\
\hline $\mathrm{Ni}$ & 0.09 & -0.11 & 0.002 & 0.35 & -0.06 & 0.39 & 1 & & & & & & & & & & & \\
\hline $\mathrm{Cu}$ & -0.04 & 0.45 & 0.42 & 0.12 & 0.05 & 0.15 & 0.52 & 1 & & & & & & & & & & \\
\hline $\mathrm{Zn}$ & 0.01 & 0.53 & 0.36 & -0.04 & 0.05 & -0.01 & 0.08 & 0.66 & 1 & & & & & & & & & \\
\hline As & 0.33 & 0.09 & -0.02 & 0.16 & 0.21 & 0.26 & 0.03 & 0.21 & -0.1 & 1 & & & & & & & & \\
\hline $\mathrm{Sr}$ & 0.49 & 0.13 & 0.08 & 0.34 & 0.03 & 0.28 & 0.14 & -0.003 & -0.08 & 0.44 & 1 & & & & & & & \\
\hline $\mathrm{Cd}$ & -0.04 & 0.15 & 0.08 & -0.03 & -0.06 & -0.04 & -0.05 & 0.21 & 0.25 & -0.12 & -0.12 & 1 & & & & & & \\
\hline $\mathrm{Ba}$ & 0.73 & -0.03 & 0.12 & 0.72 & -0.06 & 0.85 & 0.38 & 0.08 & -0.01 & 0.32 & 0.45 & -0.01 & 1 & & & & & \\
\hline $\mathrm{Pb}$ & 0.09 & 0.63 & 0.58 & 0.06 & -0.02 & 0.08 & 0.07 & 0.71 & 0.79 & -0.12 & 0.01 & 0.26 & 0.08 & 1 & & & & \\
\hline Temp & -0.04 & -0.11 & -0.19 & 0.15 & -0.05 & 0.07 & 0.19 & 0.03 & 0.06 & -0.43 & -0.06 & 0.09 & 0.09 & 0.08 & 1 & & & \\
\hline $\mathrm{pH}$ & -0.47 & 0.06 & -0.18 & -0.001 & -0.04 & -0.21 & -0.08 & -0.06 & -0.16 & -0.09 & -0.04 & -0.08 & -0.44 & -0.17 & -0.05 & 1 & & \\
\hline EC & 0.55 & -0.03 & -0.08 & 0.65 & -0.03 & 0.64 & 0.39 & 0.01 & -0.11 & 0.34 & 0.63 & -0.19 & 0.82 & -0.05 & 0.16 & -0.14 & 1 & \\
\hline TDS & 0.55 & -0.03 & -0.08 & 0.65 & -0.03 & 0.64 & 0.39 & 0.01 & -0.11 & 0.34 & 0.63 & -0.19 & 0.82 & -0.05 & 0.16 & -0.14 & 1 & 1 \\
\hline
\end{tabular}

In Table 6, PCA matrix shows a very strong positive correlation between $\mathrm{Cr} / \mathrm{V}, \mathrm{Ba} / \mathrm{Li}, \mathrm{Ba} / \mathrm{Mn}, \mathrm{Pb} / \mathrm{Ni}, \mathrm{Pb} / \mathrm{Zn} \mathrm{Cu} / \mathrm{Zn}$ and a moderately strong positive correlation between $\mathrm{Co} / \mathrm{Mn}, \mathrm{Ba} / \mathrm{Co}, \mathrm{Ba} / \mathrm{EC}$ and $\mathrm{Ba} / \mathrm{TDS}$. A high correlation coefficient (nearly 1 or -1 ) means a good relationship between two variables, and a correlation coefficient around zero means no relationship. Positive values indicate a positive relationship while negative values of $r$ indicate an inverse relationship [23].

\subsection{Hierarchical Cluster Analysis (HCA)}

The R-mode Hierarchical Cluster Analysis HCA performed on the groundwater samples produced two clusters based on spatial similarities and dissimilarities: Cluster one; (01) element Fe; soluble. Cluster two (13) non soluble elements divided into two classes; class one (09) V, As, Cd, Cr, Li, Pb, Co, Ni, Cu; less enriched. Class two (04) Mn, Ba, Sr and Zn; enriched Figure 9.

\subsection{Health Hazard Assessment}

Human health hazard assessment was done to estimate the intensity, frequency, and duration of human exposures to the trace metals. Exposure assessment was carried out by measuring the average daily dose ADD of the trace metals selected as in Table 7. Carcinogenic and non carcinogenic risk were calculated from the ADD. 
Table 7. Parameters used for estimating exposure assessment [19].

\begin{tabular}{cccc}
\hline Factor/parameter & Symbol & Units & Residential \\
\hline Exposure duration & ED & Years & 30 \\
Exposure frequency & EF & Days in year & 350 \\
Average time & AT & Years & 76.5 \\
Body weight & BW & Kg & 70 \\
Ingestion rate & IR & L/day & 2.2 \\
Contaminant concentration & C & ug/L & Table 5 \\
\hline
\end{tabular}



Figure 9. Dendrogram of trace metals in groundwater of Ekondo-Titi and environs made up of two clusters: Cluster one; (01) element Fe; soluble. Cluster two (13) non soluble elements divided into two classes; class one (09) V, As, Cd, Cr, Li, Pb, Co, Ni, C; less enriched. Class two (04) Mn, Ba, Sr and $\mathrm{Zn}$; enriched.

\subsubsection{Average Daily Dose}

ADD values ranged as follows; ( $\mathrm{Li}) 3 \times 10^{-6}$ to $2 \times 10^{-4}$, (V) $1.1 \times 10^{-6}$ to $1.8 \times$ $10^{-5}$, (Cr) $4.3 \times 10^{-6}$ to $4 \times 10^{-5},(\mathrm{Mn}) 2 \times 10^{-4}$ to $1.7 \times 10^{-2},(\mathrm{Fe}) 6 \times 10^{-4}$ to $7.8 \times$ $10^{-2}$, (Co) $7 \times 10^{-6}$ to $6 \times 10^{-4}$, (Ni) $3 \times 10^{-5}$ to $2.1 \times 10^{-3},(\mathrm{Cu}) 4 \times 10^{-5}$ to $7 \times$ $10^{-4}$, (Zn) $9 \times 10^{-5}$ to 0.02 , (As) $1 \times 10^{-6}$ to $3 \times 10^{-5}$, (Sr) $7 \times 10^{-5}$ to $6 \times 10^{-3}$, (Cd) $5 \times 10^{-7}$ to $5 \times 10^{-5}$, (Ba) $1 \times 10^{-4}$ to $0.01,(\mathrm{~Pb}) 2 \times 10^{-5}$ to $2 \times 10^{-4}$ all values are below toxic levels as in Figure 10.

\subsubsection{Hazard Qotient}

HQ values ranged as follow; (V) $5.7 \times 10^{-4}$ to $9.1 \times 10^{-3}$, (Cu) $9.5 \times 10^{-4}$ to $1.8 \times$ $10^{-2}$, (Pb) $4.8 \times 10^{-3}$ to $5.4 \times 10^{-2}$, (Zn) $3 \times 10^{-4}$ to $6.6 \times 10^{-2}$, (Fe) $8.9 \times 10^{-4}$ to 0.11 , (Mn) $1.1 \times 10^{-2}$ to 1.2 as in Figure 11 . Mn is the only trace metal with HQ value above permissible limit.

\subsubsection{Carcinogenic Risk}

The carcinogenic elements; As, $\mathrm{Cr}, \mathrm{Cd}$ and $\mathrm{Ni}$ are; (As) $2.1 \times 10^{-5}$ to $5.8 \times 10^{-4}$, (Cd) $4.3 \times 10^{-6}$ to $4.2 \times 10^{-4}$, (Cr) $2.3 \times 10^{-4}$ to $2.2 \times 10^{-3}$, (Ni) $3.6 \times 10^{-4}$ to $2.5 \times$ $10^{-3}$ as in Figure 12. All trace metals and below permissible limits thus con- 
sumption of the groundwater over time will not pose any health issues to the inhabitants of the study area.

\subsubsection{Hazard Index}

$\mathrm{HI}$ is the cumulative sum of HQ. The values ranged between 0.03 and 1.2 for each of contaminant indicating toxicity associated with Sample 29 with HI values $>1$ as in Figure 13.

All the groundwater hazard risk indices; ADD, CR, HQ and HI were less than 1 but for sample 29 which had HI value greater 1 thus the water is of significant health risk as shown in Table 8.

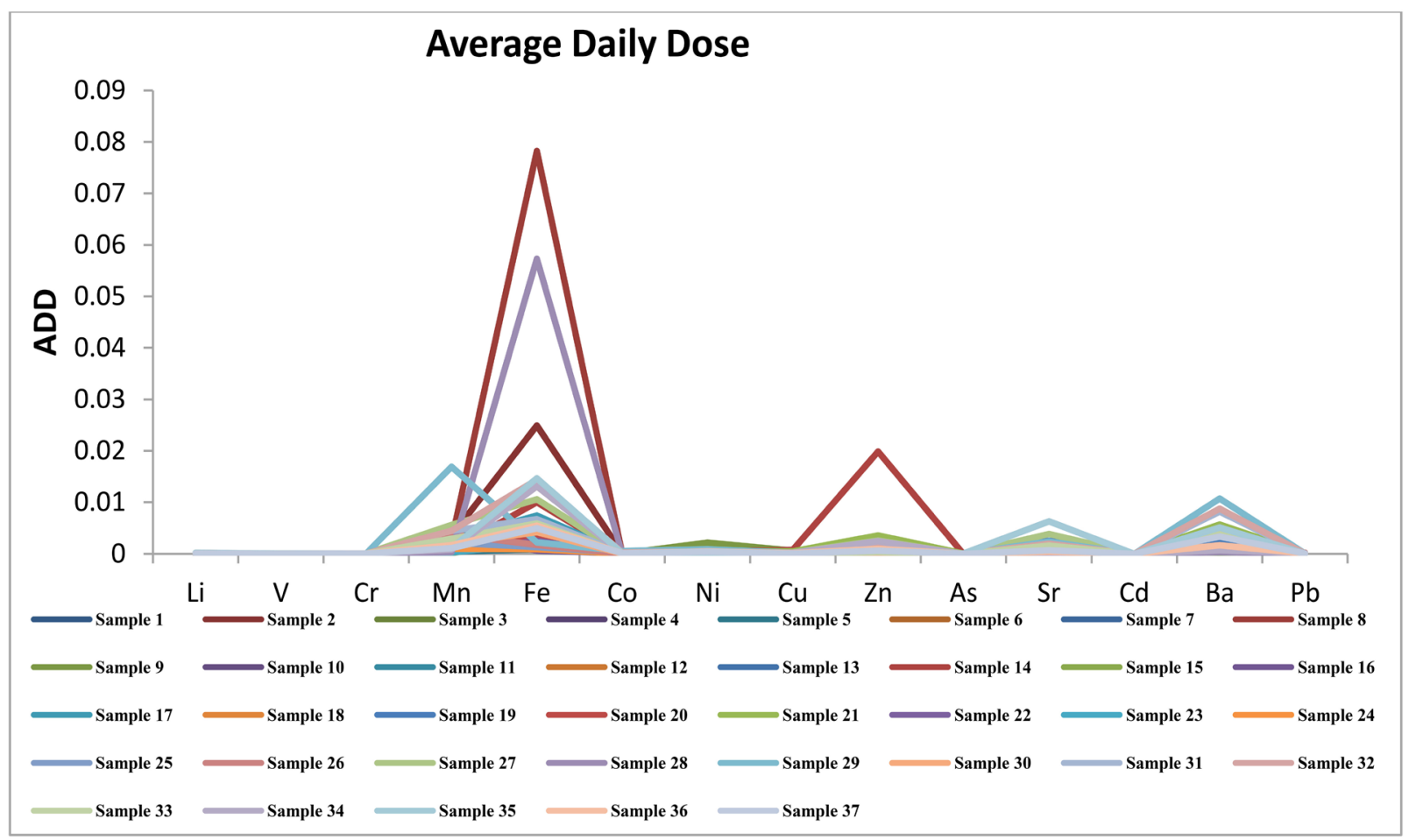

Figure 10. Average Daily Dose (ADD) of trace metals through water intake. All values are below toxic level in Ekondo-Titi and environs.



Figure 11. Hazard quotient (HQ) of trace metals through water intake. All values are below toxic levels in Ekondo-Titi and environs. 




Figure 12. Carcinogenic risk (CR) of each contaminant. All values are below toxic levels in Ekondo-Titi and environs.



Figure 13. Non carcinogenic toxic risk index or hazard index (HI) of trace metals through water intake in Ekondo-Titi and environs

Table 8. Classification of health hazard assessment carcinogenic and non-carcinogenic risk.

\begin{tabular}{cccccc}
\hline INDEX & Range & Classification & Samples & $(\%)$ & Reference \\
\hline CR & $<10^{-6}$ & cause no significant health effects & 37 & 100 & {$[25]$} \\
& $<1$ & Acceptable level (no concern) & 36 & 97.3 & \\
HQ & $>1$ & No carcinogenic adverse effects & 1 & 2.7 & {$[32]$} \\
& $<1$ & Safe & 36 & 97.3 & {$[32]$} \\
HI & $>1$ & Unsafe & 1 & 2.7 & \\
& & & &
\end{tabular}

\section{Pollution Risk Indices}

\subsection{Degree of Contamination (DC)}

The degree of contamination (DC) was used as reference of estimating the extent of metal pollution (Rubio et al., 2000). The DC values in the groundwater ranged from -13.59 to -5.62 According to classification [25], all of the samples have low 
degree of contamination factor indicating that there is no pollution.

\subsection{Enrichment Factor}

Enrichment factor is use to infer the most enriched trace metals in the study. EF values $<2$ indicate that the metal is entirely from crustal materials or natural processes; whereas EF values $>2$ reveal that the sources are more likely to be anthropogenic [33]. The enrichment factors of heavy metals in Mundemba were as shown in Figure 14, Figure 15 and Table 9. The sequence of EF in the groundwater was $\mathrm{Ba}>\mathrm{Co}>\mathrm{Pb}>\mathrm{Mn}>\mathrm{Ni}>\mathrm{Cd}>\mathrm{As}>\mathrm{Sr}>\mathrm{Cr}>\mathrm{Zn}>\mathrm{Cu}>\mathrm{Li}>$ $\mathrm{V}$. EF values in the study area is between 6.79 to 843.94 which is indicative of significant enrichment and that the source of these metals is from natural and anthropogenic processes. Barium is the most enriched element in the study area; this could be attributed to agricultural wastes.

Table 9. Summary Classification of Ekondo-Titi and environs groundwater based on pollution evaluation indices.

\begin{tabular}{lllll}
\hline INDEX & Range & Classification & Samples & $\%$ \\
\hline DC & $<10$ & low degree of contamination factor & 37 & 100 \\
& $2-5$ & Moderate enrichment & 8 & 21.6 \\
EF & $5-20$ & Significant enrichment & 14 & 37.8 \\
& $20-40$ & Very high enrichment & 15 & 40.6 \\
Er & $<40$ & Low potential risk & 37 & 100 \\
RI & $<150$ & Low ecological risk & 37 & 100 \\
PLI & $<1$ & No pollution risk & 37 & 100 \\
& $0-1$ & $\begin{array}{l}\text { Unpolluted to moderated pollution } \\
\text { risk from }\end{array}$ & $\mathrm{Li}, \mathrm{V}, \mathrm{Cr}, \mathrm{Co}, \mathrm{As}, \mathrm{Cd}, \mathrm{Pb}$ \\
Igeo & $3-4$ & Strong pollution risk from & $\mathrm{Ba}$ & \\
& $>6$ & Extreme pollution risk from & $\mathrm{Mn}, \mathrm{Fe}, \mathrm{Ni}, \mathrm{Cu}, \mathrm{Zn}, \mathrm{Sr}$ \\
\hline
\end{tabular}



Figure 14. The degree of contamination for trace metals of groundwater in Ekondo-Titi and environs with all samples having low degree of contamination values. 




Figure 15. The enrichment factor for trace metal of groundwater in Ekondo-Titi and environs, Barium is the most enriched trace metal.

\subsection{Ecological Risk Assessment}

\section{Ecological Risk Factor (Er) and Ecological Risk Index (RI)}

Er and RI of the trace metals in Ekondo-Titi and environs are given in Table 9 and Figure 16 and Figure 17. All analyzed trace metals showed low potential ecological risk varying from -29.84 to $-0.19(\mathrm{Er}<40)$. RI of the studied trace metals ranged from -62.07 to -45.53 . It is clear that all the samples show low ecological risk, this indicates low potential pollution.

\subsection{Pollution Load Index (PLI)}

Pollution load index is a quick tool in order to compare the pollution status of different places [34]. The values of Pollution Load Index are $<1$ which is indicative that there is no risk of pollution in Ekondo-Titi and environs Figure 18.

\subsection{Geo-Accumulation Index}

The geo-accumulation index is a quantitative measure of the degree of pollution in groundwater [35]. Table 10 presents the geo index for the quantification of trace metal accumulation in Ekondo-Titi and environs. Groundwater has no-pollution to moderate pollution risk from $\mathrm{Li}, \mathrm{V}, \mathrm{Cr}, \mathrm{Co}, \mathrm{Cu}, \mathrm{As}, \mathrm{Cd}$ and $\mathrm{Pb}$, strong pollution risk from $\mathrm{Ba}$ while it is extreme pollution risk from $\mathrm{Mn}, \mathrm{Ni}, \mathrm{Sr}$, Fe and $\mathrm{Zn}$ as shown in Table 9.

\section{Conclusions}

There is no trace metal pollution hazard or pollution risk in Ekondo-Titi and environs since trace metal concentrations are below WHO permissible limits.

The pollution health risk indices are all below the acceptable guideline values.

The enrichment factor showed that the sources of metals are geogenic and anthropogenic processes.

Barium is the most enriched element in the study area; this could be attributed to agricultural fertilizers. 




Figure 16. The Ecological risk factor for trace metals of groundwater in Ekondo-Titi and environs.



Figure 17. Ecological risk index for trace metal of groundwater in Ekondo-Titi and environs.



Figure 18. The Pollution load index for trace metal of groundwater in Ekondo-Titi and environs. 
R. A. Il Akoachere et al.

Table 10. The Geo-accumulation index (Igeo) of groundwater in Ekondo-Titi and environs.

\begin{tabular}{|c|c|c|c|c|c|c|c|c|c|c|c|c|c|c|}
\hline SN & $\mathbf{L i}$ & $\mathrm{V}$ & $\mathrm{Cr}$ & $\mathrm{Mn}$ & $\mathrm{Fe}$ & Co & $\mathrm{Ni}$ & $\mathrm{Cu}$ & $\mathrm{Zn}$ & As & $\mathrm{Sr}$ & $\mathrm{Cd}$ & $\mathrm{Ba}$ & $\mathrm{Pb}$ \\
\hline 1 & 0.03 & 0.008 & 0.006 & 1.615 & 23.81 & 0.002 & 0.462 & 1.68 & 24.73 & $1 \mathrm{E}-04$ & 8.87 & $8 \mathrm{E}-05$ & 0.151 & 0.024 \\
\hline 2 & 0.04 & 0.008 & 0.004 & 11.08 & 317 & 0.008 & 0.54 & 6.378 & 20.32 & 0.002 & 15.5 & $6 \mathrm{E}-05$ & 0.357 & 0.016 \\
\hline 3 & 0 & 0.011 & 0.002 & 0.532 & 29.64 & 0.003 & 0.135 & 1.997 & 5.177 & $8 \mathrm{E}-04$ & 25 & $2 \mathrm{E}-05$ & 0.061 & 0.012 \\
\hline 4 & 0.01 & 0.011 & 0.008 & 1.583 & 78.99 & 0.003 & 0.416 & 2.084 & 8.268 & $6 \mathrm{E}-04$ & 24.7 & $3 \mathrm{E}-05$ & 0.251 & 0.014 \\
\hline 5 & 0.01 & 0.002 & 0.002 & 1.311 & 11.5 & 0.001 & 0.231 & 0.886 & 6.541 & $4 \mathrm{E}-04$ & 9.93 & $3 \mathrm{E}-05$ & 0.144 & 0.012 \\
\hline 6 & 0.01 & 0.004 & 0.003 & 1.715 & 21.82 & 0.002 & 0.432 & 2.49 & 37.65 & $3 \mathrm{E}-04$ & 8.97 & $1 \mathrm{E}-04$ & 0.35 & 0.018 \\
\hline 7 & 0.02 & 0.004 & 0.002 & 4.43 & 13.5 & 0.005 & 0.495 & 1.229 & 14.46 & 7E-04 & 44.7 & $4 \mathrm{E}-05$ & 0.664 & 0.008 \\
\hline 8 & 0.02 & 0.008 & 0.004 & 8.207 & 995.4 & 0.008 & 0.854 & 1.884 & 14.75 & $5 \mathrm{E}-04$ & 45.5 & $4 \mathrm{E}-05$ & 0.758 & 0.011 \\
\hline 9 & 0.02 & 0.004 & 0.001 & 6.504 & 48.98 & 0.004 & 9.437 & 7.23 & 5.986 & $5 \mathrm{E}-04$ & 46.3 & $3 \mathrm{E}-05$ & 1.302 & 0.008 \\
\hline 10 & 0.01 & 0.011 & 0.002 & 2.14 & 30.77 & 0.002 & 0.23 & 0.551 & 2.95 & $5 \mathrm{E}-04$ & 48.4 & $1 \mathrm{E}-05$ & 1.009 & 0.009 \\
\hline 11 & 0.03 & 0.003 & 0.002 & 2.143 & 15.54 & 0.001 & 0.251 & 1.129 & 9.103 & 7E-05 & 9.09 & $3 \mathrm{E}-05$ & 0.352 & 0.011 \\
\hline 12 & 0.03 & 0.008 & 0.003 & 2.305 & 51.33 & 0.002 & 0.289 & 2.123 & 57.32 & $2 \mathrm{E}-04$ & 11.1 & $1 \mathrm{E}-03$ & 0.62 & 0.018 \\
\hline 13 & 0.09 & 0.014 & 0.008 & 12.58 & 84.4 & 0.008 & 1.571 & 4.85 & 84.55 & $5 \mathrm{E}-04$ & 50.6 & $1 \mathrm{E}-04$ & 2.234 & 0.049 \\
\hline 14 & 0.05 & 0.023 & 0.009 & 2.461 & 127.8 & 0.003 & 1.757 & 9.178 & 632.2 & $2 \mathrm{E}-04$ & 18.7 & $2 \mathrm{E}-04$ & 0.657 & 0.084 \\
\hline 15 & 0.02 & 0.005 & 0.002 & 1.381 & 27.64 & 0.002 & 0.303 & 1.003 & 37.94 & $1 \mathrm{E}-04$ & 7.64 & $6 \mathrm{E}-05$ & 0.6 & 0.014 \\
\hline 16 & 0.09 & 0.001 & 0.002 & 12.53 & 7.964 & 0.006 & 0.739 & 0.929 & 15.95 & $5 \mathrm{E}-04$ & 25.7 & $3 \mathrm{E}-05$ & 1.306 & 0.01 \\
\hline 17 & 0.09 & 0.023 & 0.011 & 8.946 & 94.52 & 0.006 & 1.045 & 4.871 & 96.82 & $3 \mathrm{E}-04$ & 21.7 & $2 \mathrm{E}-04$ & 1.187 & 0.058 \\
\hline 18 & 0.02 & 0.009 & 0.002 & 3.871 & 23.02 & 0.003 & 0.324 & 1.286 & 24.37 & $2 \mathrm{E}-04$ & 17.8 & $4 \mathrm{E}-05$ & 0.592 & 0.013 \\
\hline 19 & 0.02 & 0.006 & 0.002 & 9.657 & 22.74 & 0.004 & 0.438 & 0.738 & 6.998 & $4 \mathrm{E}-04$ & 64.4 & $4 \mathrm{E}-05$ & 0.922 & 0.011 \\
\hline 20 & 0.03 & 0.005 & 0.003 & 5.012 & 43.15 & 0.006 & 0.944 & 2.076 & 37.84 & $2 \mathrm{E}-04$ & 18.8 & 7E-05 & 0.739 & 0.021 \\
\hline 21 & 0.04 & 0.01 & 0.01 & 8.541 & 62.96 & 0.013 & 2.218 & 5.608 & 112.9 & $4 \mathrm{E}-04$ & 39 & $1 \mathrm{E}-04$ & 2.517 & 0.05 \\
\hline 22 & 0.02 & 0.013 & 0.013 & 1.014 & 31.38 & 0.001 & 0.388 & 1.994 & 5.012 & $6 \mathrm{E}-05$ & 20.7 & $2 \mathrm{E}-05$ & 0.288 & 0.013 \\
\hline 23 & 0.02 & 0.019 & 0.007 & 0.889 & 26.33 & 0.001 & 0.393 & 1.898 & 21.11 & $9 \mathrm{E}-05$ & 26.6 & $6 \mathrm{E}-05$ & 0.245 & 0.016 \\
\hline 24 & 0.01 & 0.005 & 0.002 & 2.947 & 11.12 & 0.002 & 0.374 & 1.345 & 8.439 & 7E-05 & 22.7 & $4 \mathrm{E}-05$ & 0.277 & 0.012 \\
\hline 25 & 0.03 & 0.003 & 0.001 & 6.834 & 16.95 & 0.01 & 1.093 & 1.034 & 9.029 & $3 \mathrm{E}-04$ & 39.6 & $4 \mathrm{E}-05$ & 1.605 & 0.014 \\
\hline 26 & 0.06 & 0.003 & 0.001 & 11.88 & 22.3 & 0.002 & 0.27 & 0.488 & 4.213 & $6 \mathrm{E}-05$ & 47.1 & $1 \mathrm{E}-05$ & 0.318 & 0.009 \\
\hline 27 & 0.05 & 0.011 & 0.005 & 17.74 & 134.7 & 0.004 & 0.856 & 3.447 & 81.63 & $3 \mathrm{E}-04$ & 97.6 & $1 \mathrm{E}-04$ & 0.501 & 0.049 \\
\hline 28 & 0.01 & 0.009 & 0.002 & 0.951 & 729.3 & $4 \mathrm{E}-04$ & 0.15 & 0.635 & 62.45 & $3 \mathrm{E}-04$ & 1.89 & $2 \mathrm{E}-05$ & 0.154 & 0.008 \\
\hline 29 & 0.14 & 0.003 & 0.003 & 53.82 & 27.99 & 0.036 & 4.028 & 2.515 & 34.31 & $4 \mathrm{E}-04$ & 60.1 & 9E-05 & 4.765 & 0.015 \\
\hline 30 & 0.15 & 0.017 & 0.004 & 6.249 & 53.27 & 0.004 & 0.562 & 0.759 & 5.22 & $8 \mathrm{E}-04$ & 49.7 & $2 \mathrm{E}-05$ & 1.765 & 0.008 \\
\hline 31 & 0.11 & 0.005 & 0.002 & 14.3 & 85.12 & 0.011 & 1.059 & 1.444 & 26.28 & 0.001 & 45.4 & 7E-05 & 3.664 & 0.011 \\
\hline 32 & 0.23 & 0.013 & 0.007 & 14.25 & 182.5 & 0.016 & 1.737 & 2.368 & 45.26 & $8 \mathrm{E}-04$ & 49.7 & $8 \mathrm{E}-05$ & 3.902 & 0.03 \\
\hline 33 & 0.22 & 0.003 & 0.003 & 9.403 & 74.79 & 0.004 & 0.504 & 0.648 & 9.973 & $3 \mathrm{E}-04$ & 39.5 & $2 \mathrm{E}-05$ & 1.714 & 0.011 \\
\hline 34 & 0.03 & 0.011 & 0.005 & 2.525 & 166.4 & 0.002 & 0.521 & 2.113 & 77.83 & $1 \mathrm{E}-04$ & 6.8 & 7E-05 & 0.31 & 0.039 \\
\hline 35 & 0.19 & 0.013 & 0.007 & 3.556 & 186.4 & 0.006 & 0.648 & 1.439 & 29.29 & 0.001 & 160 & $5 \mathrm{E}-05$ & 2.275 & 0.015 \\
\hline 36 & 0.06 & 0.005 & 0.004 & 5.287 & 69.58 & 0.005 & 2.1 & 0.967 & 31.17 & $1 \mathrm{E}-04$ & 10.1 & $3 \mathrm{E}-05$ & 0.725 & 0.019 \\
\hline 37 & 0.07 & 0.005 & 0.009 & 3.413 & 63.09 & 0.008 & 1.866 & 0.929 & 18.42 & 9E-05 & 17.2 & $2 \mathrm{E}-05$ & 1.501 & 0.01 \\
\hline Min & 0 & 0.001 & 0.001 & 0.532 & 7.964 & $4 \mathrm{E}-04$ & 0.135 & 0.488 & 2.95 & $6 \mathrm{E}-05$ & 1.89 & $1 \mathrm{E}-05$ & 0.061 & 0.008 \\
\hline Max & 0.23 & 0.023 & 0.013 & 53.82 & 995.4 & 0.036 & 9.437 & 9.178 & 632.2 & 0.002 & 160 & $1 \mathrm{E}-03$ & 4.765 & 0.084 \\
\hline Mean & 0.06 & 0.009 & 0.004 & 7.125 & 108.5 & 0.006 & 1.072 & 2.276 & 46.66 & $4 \mathrm{E}-04$ & 34 & $8 \mathrm{E}-05$ & 1.102 & 0.02 \\
\hline
\end{tabular}


Groundwater has no-pollution to moderately pollution risk from $\mathrm{Li}, \mathrm{V}, \mathrm{Cr}$, $\mathrm{Co}, \mathrm{As}, \mathrm{Cd}, \mathrm{Pb}$ while groundwater has a strong pollution risk from $\mathrm{Ba}$ and extreme pollution risk from $\mathrm{Mn}, \mathrm{Sr}, \mathrm{Fe}$ and $\mathrm{Zn}$, though the concentrations of these trace metals are below WHO guidelines.

From the health hazard indices and pollution risk indices on trace metals, the groundwater in Ekondo-Titi and environs is safe for drinking.

The severity of metal toxicity is governed by several factors, such as dose, nutrition, age, and even life style. Therefore, these low trends that indicate the absence of human health hazards and health risks, the groundwater, might not guarantee the complete and permanent absence of human health hazards and risks due to an increasing level of environmental pollution that might be imposed by the increasing plantation agriculture in this area.

Groundwater sources might become a potential sink of contaminants; this is the reason for recommending a constant monitoring and implementation program in Ekondo-Titi and environs.

\section{Conflicts of Interest}

The authors declare no conflicts of interest regarding the publication of this paper.

\section{References}

[1] Adepoju-Bello, A.A., Ojomolade, O.O., Ayoola, G.A. and Coker, H.A.B. (2009) Quantitative Analysis of Some Toxic Metals in Domestic Water Obtained from Lagos Metropolis. The Nigerian Journal of Pharmacy, 42, 57-60.

[2] Defo, C., Yerima, B.P.K., Noumsi, I.M.K. and Bemm, N. (2015) Assessment of Heavy Metals in Soils and Groundwater in an Urban Watershed of Yaoundé (Cameroon-West Africa). Environmental Monitoring and Assessment, 187, 1-17. https://doi.org/10.1007/s10661-015-4292-1

[3] Akoachere, R.A., Etone, E.N., Mbua, R.L., Ngassam, M.P., Longonje, S.N., Oben, P.M. and Engome, R.W. (2019) Trace Metals in Groundwater of the South Eastern Piedmont Region of Mount Cameroon: Quantification and Health Risk Assessment. Open Access Library Journal, 6, e5327.

[4] Verma, R. and Dwivedi, P. (2013) Heavy Metal Water Pollution-A Case Study. Recent Research in Science and Technology, 5, 98-99.

[5] Fraser, J.P., Hall, J.B. and Healey, J.R. (1998) Climate of Mount Cameroon Region; Long and Medium Term Rainfall, Temperature and Sunshine Data. University of Wales, Bangor, 56.

[6] Fitton, J.D. (1980) The Benue Trough and the Cameroon Line a Migrating Rift System in West Africa. Earth and Planetary Science Letters, 51, 132-138. https://doi.org/10.1016/0012-821X(80)90261-7

[7] Fitton, J.D. and Dunlop, H.M. (1985) The Cameroon Line, West Africa and Its Bearing on the Origin of Oceanic and Continental Alkali Basalts. Earth and Planetary Science Letters, 72, 23-38. https://doi.org/10.1016/0012-821X(85)90114-1

[8] Halliday, A.N., Dicken, A.P., Fallick, A.E. and Fitton, J.D. (1988) Mantle Dynamics: a $\mathrm{Nd}, \mathrm{Sr}, \mathrm{Pb}$ and $\mathrm{Os}$ Isotope Study of the Cameroon Line Volcanic Chain. Journal of Petrology, 29, 181-211. https://doi.org/10.1093/petrology/29.1.181 
[9] Halliday, A.N., Davidson, J.P., Holden, P., Dewolf, C.P., Lee, D.C. and Fitton, D.G. (1990) Trace Element Fractionation in Plume and the Origin of HIMU Mantle beneath the Cameroon Line. Nature, 347, 523-528. https://doi.org/10.1038/347523a0

[10] Poudjom Djomani, Y.H., Diament, M. and Wilson, M. (1997) Lithospheric Structure across the 1159 Adamawa Plateau (Cameroon) from Gravity Studies. Tectonophysics, 273, 317-327. https://doi.org/10.1016/S0040-1951(96)00280-6

[11] Ubangoh, R.U. (1998) Estudo paleomagnético do vulcanismo terciário da Republica dos Camarões. PhD Thesis, São Paulo, Brazil.

[12] Nono, A., Njonfang, E., Kagou Dongmo, A., Nkouathio, D.G. and Tchoua, F.M. (2004) Pyroclastic Deposits of the Bambouto Volcano (Cameroon Line, Central Africa): Evidence of a Strombolian Initial Phase. Journal of African Earth Science, 39, 409-414. https://doi.org/10.1016/j.jafrearsci.2004.07.026

[13] Ngako, V., Njonfang, E., Aka, F.T., Affaton, P. and Metuk Nnange, J. (2006) The North-South Paleozoic to Quaternary Trend of Alkaline Magnetism from Niger-Nigeria to Cameroon: Complex Interaction between Hotspots and Precambrian Faults. Journal of African Earth Science, 45, 241-256. https://doi.org/10.1016/j.jafrearsci.2006.03.003

[14] Fairhead, J.D. and Binks, R.M. (1991) Differential Opening of the Central and South Atlantic Oceans and the Opening of the West African System. Tectonophysics, 187, 191-203. https://doi.org/10.1016/0040-1951(91)90419-S

[15] Smith, A. and Livermore, R.A. (1991) Pangea in Permian to Jurassic Time. Tectonophysics, 187, 135-179. https://doi.org/10.1016/0040-1951(91)90417-Q

[16] Dumort, J.C. (1968) Reconnaissance Geologic Map of Douala-West (1:500000) and Explanatory Notes. Federal Republic of Cameroon, Directorate of Mines and Geology Cameroon, 69.

[17] Paustenbach, D.J. (2002) Human and Ecological Risk Assessment: Theory and Practice. John Wiley and Sons, New York.

[18] Hu, X., Zhang, Y., Ding, Z.H., Wang, T.J., Lian, H.Z. and Sun, Y.Y. (2012) Bio-Accessibility and Health Risk of Arsenic and Heavy Metals (Cd, Co, Cr, Cu, Ni, $\mathrm{Pb}, \mathrm{Zn}$ and $\mathrm{Mn}$ ) in TSP and PM2. 5 in Nanjing, China. Atmospheric Environment, 57, 146-152. https://doi.org/10.1016/j.atmosenv.2012.04.056

[19] Lushenko, M.A. (2010) A Risk Assessment for Ingestion of Toxic Chemicals in Fish from Imperial Beach. San Diego State University, San Diego, CA.

[20] Koki, I.B., Bayero, A.S., Umar, A. and Yosuf, S. (2015) Health Risk Assessment of Heavy Metals in Water, Air, Soil and Fish. African Journal of Pure and Applied Chemistry, 9, 204-210. https://doi.org/10.5897/AJPAC2015.0654

[21] Kamunda, C., Mathuthu, M. and Madhuku, M. (2016) Health Risk Assessment of Heavy Metals in Soils from Witwatersrand Gold Mining Basin, South Africa. International Journal of Environmental Research and Public Health, 13, E663. https://doi.org/10.3390/ijerph13070663

[22] Song, D., Zhuang, D., Jiang, D., Fu, J. and Wang, Q. (2015) Integrated Health Risk Assessment of Heavy Metals in Suxian County, South China. International Journal of Environmental Research and Public Health, 12, 7100-7117. https://doi.org/10.3390/ijerph120707100

[23] Kim, E.J., Herrera, J.E., Huggins, D., Braam, J. and Koshowki, S. (2011) Effect of pH on the Concentrations of Lead and Trace Contaminants in Drinking Water: A Combined Batch, Pipe Loop and Sentinel Home Study. Water Research, 45, 2763-2774. https://doi.org/10.1016/j.watres.2011.02.023 
[24] Kolluru, R.V., Bartell, S.M., Pitblado, R.M. and Stricoff, R.S. (1996) Risk Assessment and Management Handbook. McGraw-Hill, New York.

[25] Edet, A.E. and Offiong, O.E. (2002) Evaluation of Water Quality Pollution Indices for Heavy Metal Contamination Monitoring. A Study Case from Akpabuyo-Odukpani Area Lower Cross River Basin (Southeastern Nigeria). GeoJournal, 57, 295-304. https://doi.org/10.1023/B:GEJO.0000007250.92458.de

[26] Zhang, L.P., Ye, X., Feng, H., et al. (2007) Heavy Metal Contamination in Western Xiamen Bay Sediments and Its Vicinity, China. Marine Pollution Bulletin, 54, 974-982. https://doi.org/10.1016/j.marpolbul.2007.02.010

[27] Hakanson, L. (1980) An Ecological Risk Index for Aquatic Pollution Control. A Sedimentological Approach. Water Research, 14, 975-1001.

https://doi.org/10.1016/0043-1354(80)90143-8

[28] Harikumar, P.S., Nasir, U.P. and Rahman, M.M. (2009) Distribution of Heavy Metals in the Core Sediments of a Tropical Wetland System. International Journal of Environmental Science \& Technology, 6, 225-232. https://doi.org/10.1007/BF03327626

[29] Ji, Y., Feng, Y., Wu, J., Zhu, T., Bai, Z. and Duan, C. (2008) Using Geo-Accumulation Index to Study Source Profiles of Soil Dust in China. Journal of Environmental Sciences, 20, 571-578. https://doi.org/10.1016/S1001-0742(08)62096-3

[30] WHO (2011) Guidelines for Drinking-Water Quality. 1-541

[31] Mbotake, I.T. (2006) A Preliminary Study of Sources of Arsenic Contamination in Southwest Cameroon. Journal of Environmental Hydrogeology, 14, 1-11.

[32] USEPA (2012) Waste and Clean up Risk Assessment. http://www2.epa.gov/risk/waste-and-cleanup-risk-assessment

[33] Liaghati, T., Preda, M. and Cox, M. (2003) Heavy Metal Distribution and Controlling Factors within Coastal Plain Sediments, Bells Creek Catchment, Southeast Queensland, Australia. Environment International, 29, 935-948. https://doi.org/10.1016/S0160-4120(03)00060-6

[34] Adebowale, K.O., Agunbide, F.O. and OluOwolabi, B. (2009) Trace Metal Concentration, Site Variations and Partitioning Pattern in Water and Bottom Sediments from Coastal Area: A Case Study of Ondo Coast, Nigeria. Environmental Research Journal, 3, 46-59.

[35] Singh, M., Ansari, A.A., Müller, G. and Singh, I.B. (1997) Heavy Metals in Freshly Deposited Sediments of the Gomati River (a Tributary of the Ganga River): Effects of Human Activities. Environmental Geology, 29, 246-252. https://doi.org/10.1007/s002540050123 